\title{
Multiple Regression Analysis of Class Teacher's Effect on Students "Incremental" of Academic Performance
}

\author{
Zhang Zhiquan ${ }^{1}$, Jieyin ${ }^{2}$
}

Educational faculty of Nantong University Jiangsu Nantong

\begin{abstract}
Class student achievement "increase" is affected by multiple factors, include not only schools, teachers, families, but also include the students themselves. the researchers assumed class teacher were the most important factor in affecting students ' academic achievement increase and devoted to discuss class teacher's academic qualifications, job title, career age ,gender's impact on students. Through collecting data of six thousand students (include data of their family), five hundred teachers and sixty schools, using Spss and HLM software for analysis. We get the conclusion that family background, school size, especially teacher education, gender, age, title have significant effect on students' academic achievement increase.
\end{abstract}

Keywords: the quality of teacher; education function; academic achievement

\section{INTRODUCTION}

In the present education in china, society, school and parents pay more attention not on the development of youth's interest and ability, but on the increasing of students' knowledge test score. That's make the Chinese student study knowledge hard all day and have no time to develop their interest and ability. For example one Chinese primary student will spend 9 hours on studying knowledge and junior middle school student spend eleven hours and senior middle school student even more. Maybe, that's not the only problem of Chinese education, another problem exist in Chinese education is its evaluation, in the past and nowadays, in most time, evaluation on students not to see how much progress they make in one test compare last test, but to see the absolute score students get in one test. That makes a lot of student lose their heart after many test. In order to change the situation, in this article, we pay more attention on the progress student make in every test and find which factors affect the students' progress most. In order to carry out the test, we select 6000 students (among these are 1516 primary boy students, 1484primary girl students, 1578 boy and 1422 girl middle school student) and 520 teachers in twenty schools. The exact number is list 1-1, 1-2 and 1-3.

Table1.1. Information of middle school student

\begin{tabular}{|l|l|l|l|l|l|l|l|l|l|}
\hline \multirow{2}{*}{ Characteristic of sample } & \multicolumn{2}{|l|}{ sex } & \multicolumn{3}{l|}{ School position } & \multicolumn{3}{l|}{ grade } \\
\cline { 2 - 9 } & male & female & county & city & & 1 & 2 & 3 \\
\hline Sample number & 1578 & 1422 & 2010 & 900 & 900 & 900 & 1200 \\
\hline percent $(\%)$ & 52.6 & 47.4 & 70.1 & 29.9 & 30 & 30 & 40 \\
\hline
\end{tabular}

Table1.2. information of primary school student

\begin{tabular}{|l|l|l|l|l|l|l|l|l|l|}
\hline \multirow{2}{*}{ sample Characteristic } & \multicolumn{2}{|l|}{ sex } & \multicolumn{3}{l|}{ School position } & \multicolumn{3}{l|}{ grade } \\
\cline { 2 - 10 } & male & girl & couny & city & 3 & 4 & 5 \\
\hline Sample number & 1516 & 1484 & 989 & 511 & 900 & 900 & 1200 \\
\hline percent $(\%)$ & 50.5 & 49.5 & 66 & 34 & 30 & 30 & 40 \\
\hline
\end{tabular}

${ }^{1}$ Corresponding Author: zzhq110@sina.com

Jie yin(1993-), male, born in Nantong city, postgraduate, studying educational principle theory in educational faculty in Nantong university. ,

This article is the achievement of the National Science Education 1025 planning key project: excellent teacher training effectiveness "value-added" evaluation research, approval number: DIA150318 
Table.1.3 information of teacher

\begin{tabular}{|c|c|c|c|c|c|c|c|c|c|c|c|c|}
\hline \multirow{2}{*}{$\begin{array}{l}\text { sample } \\
\text { Characteristic }\end{array}$} & \multicolumn{3}{|c|}{ sex } & \multicolumn{4}{|c|}{ School position } & \multicolumn{5}{|c|}{ Teaching time } \\
\hline & male & \multicolumn{2}{|c|}{ female } & \multicolumn{2}{|c|}{ county } & \multicolumn{2}{|c|}{ city } & $<5$ & $5-10$ & $11-20$ & $21-30$ & $>31$ \\
\hline Sample number & 130 & \multicolumn{2}{|r|}{389} & \multicolumn{2}{|l|}{401} & \multicolumn{2}{|c|}{119} & 114 & 200 & 149 & 49 & 8 \\
\hline percent $(\%)$ & 25.1 & \multicolumn{2}{|c|}{74.9} & \multicolumn{2}{|c|}{77.2} & \multicolumn{2}{|c|}{22.8} & 21.9 & 38.4 & 28.6 & 9.5 & 1.6 \\
\hline \multirow{2}{*}{$\begin{array}{c}\text { sample } \\
\text { Characteristic }\end{array}$} & \multicolumn{8}{|c|}{ professional title } & \multicolumn{4}{|c|}{ Educational record } \\
\hline & $\begin{array}{l}\text { The } \\
\text { primary }\end{array}$ & $\begin{array}{c}\text { Primary } \\
\text { level }\end{array}$ & \multicolumn{2}{|c|}{ Level 2} & \multicolumn{3}{|c|}{$\begin{array}{l}\text { Senior } \\
\text { level }\end{array}$} & other & bachelor & \multicolumn{2}{|c|}{ Specialty } & Other \\
\hline Sample number & 97 & 134 & \multicolumn{2}{|c|}{136} & \multicolumn{3}{|c|}{93} & 23 & 152 & \multicolumn{2}{|c|}{346} & 224 \\
\hline \multirow[t]{2}{*}{ percent $(\%)$} & 18.6 & 25.8 & \multicolumn{2}{|c|}{26.1} & \multicolumn{3}{|c|}{25.1} & 4.4 & 29.2 & \multicolumn{2}{|c|}{66.5} & 4.3 \\
\hline & & & \multicolumn{2}{|c|}{ Subject teacher } & & & & & & & & \\
\hline \multirow{2}{*}{$\begin{array}{l}\text { sample } \\
\text { Characteristic }\end{array}$} & \multicolumn{4}{|c|}{ Primary subject } & \multicolumn{8}{|c|}{ Middle school subject } \\
\hline & Chinese & math & English & other & & nese & $\mathrm{ma}$ & & English & & ience & history \\
\hline Sample number & 133 & 54 & 52 & 26 & 48 & & 36 & & 38 & 7 & & 46 \\
\hline percent $(\%)$ & 50.6 & 20.1 & 19.9 & 10.4 & 20 & & 14. & & 15.9 & & .1 & 19 \\
\hline
\end{tabular}

\subsection{Measure}

\subsubsection{Family social and economic status}

Scholars at home and abroad usually regard family income, parents education level and occupation as the 3 variables in synthesizing family social and economic status index (Bradley \& Corwyn, 2002; Chunrong Ren, 2010) othe survey of family income refer to the related research of Fuzhen Xu Wenxin Zhang(2009), combined with the actual situation of the local economy, we divided family income into"below 20 thousand 、 20 30thousand 、 30 40thousand......90-100thousand $¥$ and the above. and give them separate number of 1 10.

The education level of parents include: primary or below 、 junior middle school、senior high school or Secondary specialized school、Junior College、Undergraduate、Graduate (include master and doctor), give them separate number of 1 6.

Parent career occupation include: peasant, worker, teacher or research, government cadres or civil servants, lawyer, engineer, business management personnel, accountant, armyman, Individual / private enterprise owners, The self-employed or laid-off workers, free-lancer and other.(fuzhen Xu, wenxin zhang,2009) ,In accordance with the criteria for the classification of occupations, occupation is divided into 5 levels, respectively, the assignment is $1 \sim 5 .[1]$

\subsubsection{School status}

On the location of the school, township is 0 , city is 1 , the school founding history is $1 \sim 29$, Per capita area schools (provided by the school). Teacher and student ratio, teacher professional title ratio, make data statistics on male and female class teacher ratio and other, At the same time, the class teacher and the teacher's gender (female 0, male 1), working age, title (primary for 1 , Intermediate 2 , senior 3 ). The teacher's qualifications are mainly divided into 
American Research Journal of Humanities and Social Sciences, Volume 1, Issue 5, 2015

ISSN 2378-7031

technical secondary school, college, Graduate four grades, respectively the assignment 1 4.

\subsubsection{Academic performance}

Students' performance mainly include: student's Chinese language, mathematics, foreign language scores as measurement object. We will make a minus between the score of this term and last term. We will use the intercept to analysis the factor of effecting students' score.

\subsection{Method}

Use Spss12.0AMOS7.0 software and HLM 6.08 software to analysis the data.

\section{RESEARCH OUTCOME}

2.1. Preliminary statistical analysis

2.1.1. The influence of the teacher's post qualification on the learning achievement increment of primary and middle school students

Table.2.1 The influence of the teacher's qualification on the junior middle school students' learning achievement increment

\begin{tabular}{|l|l|l|l|l|l|}
\hline & $\begin{array}{l}\text { regression } \\
\text { coefficient }(b)\end{array}$ & $\begin{array}{l}\text { standard } \\
\text { error }\end{array}$ & $\begin{array}{l}\text { Standardized regression } \\
\text { coefficient }(\beta)\end{array}$ & $T$ test & $\Delta R^{2}$ \\
\hline sex & 0.02 & 0.01 & 0.03 & 1.48 & \\
\hline grade & 0.06 & 0.01 & 0.12 & $6.46^{* * *}$ \\
\hline School position & -0.03 & 0.06 & -0.03 & -0.41 \\
\hline School history & 0.01 & 0.00 & 0.23 & $7.60^{* * *}$ \\
\hline Per capita building area & 0.00 & 0.00 & 0.35 & $11.58^{* * *}$ \\
\hline pupil ratio & 2.01 & 0.75 & 0.10 & $2.39^{* * * *}$ \\
\hline senior professional ratio & -10.58 & 0.89 & -0.42 & $-11.89^{* * *}$ \\
\hline Teaching expert ratio & 13.56 & 2.68 & 0.32 & $5.07^{* * *}$ & \\
\hline Economic status & -0.05 & 0.01 & -0.07 & $-3.35^{* * *}$ & \\
\hline Teacher age & 0.01 & 0.00 & 0.12 & $2.53^{*}$ & \\
\hline Teacher sex & -0.03 & 0.02 & -0.04 & $-2.10^{*}$ \\
\hline Teacher education & 0.04 & 0.03 & 0.03 & 1.51 & \multirow{2}{*}{$0.01 * * *$} \\
\hline Teacher teaching time & -0.01 & 0.00 & -0.22 & $-4.47^{* * *}$ & \\
\hline Average education years & -0.02 & 0.02 & -0.02 & -0.89 & \\
\hline Average length of service & -0.01 & 0.00 & -0.05 & $-2.63^{* *}$ & \\
\hline
\end{tabular}

note: $* p<0.05, * * p<0.01, * * * p<0.001$, the same below。

In order to explore the influence of the teacher's qualification on the students' learning achievement, this paper carries out a two step regression analysis. The first step is putting the primary school students sex, grade, school location, founding history, construction area per capita, teacher-student ratio, senior titles ratio, teaching experts ratio, social economic status of students' family into regression equation; the second step is putting teachers' Entry qualification (age, gender, education level and length of service) into the regression equation, the purpose is to 
American Research Journal of Humanities and Social Sciences, Volume 1, Issue 5, 2015

ISSN 2378-7031

investigate the pure effect of teacher qualification on students learning achievement after controlled the first step variables.

Table.2.2 influence of the teacher's qualification on incremental achievement of primary school students

\begin{tabular}{|l|l|l|l|l|l|}
\hline & $\begin{array}{l}\text { regression } \\
\text { coefficient }(b)\end{array}$ & $\begin{array}{l}\text { standard } \\
\text { error }\end{array}$ & $\begin{array}{l}\text { standardized regression } \\
\text { coefficient }(\beta)\end{array}$ & $T$ test & $\Delta R^{2}$ \\
\hline sex & -0.07 & 0.05 & -0.04 & -1.52 & \\
\hline grade & 0.02 & 0.03 & 0.02 & 0.67 \\
\hline School position & -0.14 & 0.23 & -0.07 & -0.61 \\
\hline School history & 0.01 & 0.00 & 0.12 & $2.29^{*}$ \\
\hline Per capita building area & 0.01 & 0.01 & 0.03 & 0.65 \\
\hline pupil ratio & -1.06 & 1.69 & -0.04 & -0.63 \\
\hline Senior rofessionalatio & -1.85 & 4.61 & -0.02 & -0.40 \\
\hline Teaching expert ratio & 7.03 & 10.50 & 0.11 & 0.67 \\
\hline Economic status & 0.01 & 0.03 & 0.01 & 0.38 \\
\hline Teacher age & 0.01 & 0.01 & 0.10 & 1.62 \\
\hline Teacher sex & -0.01 & 0.07 & 0.00 & -0.14 \\
\hline Teacher education & 0.17 & 0.08 & 0.07 & $2.23^{*}$ \\
\hline Teacher teaching time & -0.01 & 0.01 & -0.08 & -1.29 \\
\hline Average education years & -0.05 & 0.03 & -0.05 & -1.87 \\
\hline Average length of service & -0.01 & 0.00 & -0.13 & $-4.04 * * *$ \\
\hline
\end{tabular}

From Table :2-1,we can know students' gender, grade, school location, founding history, per capita construction area, teacher-student ratio, senior titles ratio, teaching experts ratio, social economic status, and so on can explain 39\% variation of middle school student score. Among the above factors, students grade, founding history, per capita construction area, teachers and students ratio, senior titles ratio, teaching experts ratio, social economic status have predictive and obvious effect on the incremental of middle school students' learning achievement.

After controlled the variables of the first step, the teacher's entry qualification (teacher's age, gender and length of service) has a significant impact on the students' academic achievement increment, which can explain the $1 \%$ variation of the middle school students' academic performance. That is to say, the pure effect of the class(in charge of class)teacher has reached $1 \%$. Specifically, the class teacher education and the average education level have no significant impact on the academic performance of middle school students. That may be related to the relative balance of junior high school teacher's academic level and little difference (almost all are undergraduate degree). But the teacher's age, gender, length of service and the average length of service can significantly predict the increment of middle school students learning achievement. The results showed that teacher who has bigger length of service and age on work has rich experience in impacting incremental of primary school students' learning achievement. However, if the teacher's age is too large, it will have a negative impact on the students' performance.

Table 2-2 shows that student gender, grade, school location, school founding history, per capita construction area, teacher-student ratio, senior titles ratio, teaching experts ratio, social economic status and so on can explain $1 \%$ variation of primary school students learning achievement ; Among these factors, only the founding history of primary school has significant predict and obvious effect on students' increment of learning achievement. This 
American Research Journal of Humanities and Social Sciences, Volume 1, Issue 5, 2015

ISSN 2378-7031

reason may be that the school which has longer history most are key school.

After controlled the variables of the first step, teacher's job qualifications (class teacher's age, gender and length of service) have a significant impact on incremental of students' learning achievement, which can explain $2 \%$ variation of the primary school students' academic performance. That is to say, the pure influence of class teacher on primary school students' academic achievement was $2 \%$. Specifically, class teachers' age and gender have no significant effect on the increment of students' academic achievement. but the teacher's academic qualifications and the average length of service can significantly predict the increment of students' learning achievement. One thing need to emphasize is that teacher's education level has positive impact on students' academic performance while their length of service has a negative impact on students' academic performance. Only appropriate length of service (close to the average length of service) is conducive to the increase of students' learning achievement.

2.1.2the influence of the teacher's qualification on the middle school students' subject academic achievement increment

Table.2.3 Influence of class teacher qualification on increment of junior high school students' Chinese achievement

\begin{tabular}{|c|c|c|c|c|c|}
\hline & $\begin{array}{l}\text { regression } \\
\text { coefficient } \\
\text { (b) }\end{array}$ & standard error & $\begin{array}{l}\text { standardized regression } \\
\text { coefficient }(\beta)\end{array}$ & $T$ test & $\Delta R^{2}$ \\
\hline sex & 0.05 & 0.02 & 0.05 & $2.41 *$ & \multirow{9}{*}{$0.26 * * *$} \\
\hline grade & 0.17 & 0.02 & 0.24 & $11.45^{* * *}$ & \\
\hline School position & 0.91 & 0.10 & 0.63 & $9.15 * * *$ & \\
\hline School history & 0.01 & 0.00 & 0.10 & $3.02 * *$ & \\
\hline Per capita building area & 0.00 & 0.00 & 0.05 & 1.52 & \\
\hline pupil ratio & 13.23 & 1.20 & 0.46 & $11.04 * * *$ & \\
\hline Senior professional ratio & 8.03 & 1.43 & 0.22 & $5.62 * * *$ & \\
\hline Teaching expert ratio & -20.87 & 4.29 & -0.34 & $-4.86^{* * *}$ & \\
\hline Economic status & -0.04 & 0.02 & -0.04 & -1.85 & \\
\hline Teacher age & 0.01 & 0.01 & 0.05 & 0.95 & \multirow{6}{*}{$0.02 * * *$} \\
\hline Teacher sex & -0.01 & 0.02 & -0.01 & -0.43 & \\
\hline Teacher education & -0.12 & 0.04 & -0.06 & $-2.89 * *$ & \\
\hline Teacher teaching time & 0.00 & 0.01 & -0.03 & -0.61 & \\
\hline Average education years & -0.13 & 0.03 & -0.11 & $-4.74 * * *$ & \\
\hline Average length of service & 0.02 & 0.00 & 0.08 & $3.44 * * *$ & \\
\hline
\end{tabular}

Table.3.4 Effect of class teacher's qualification on increment of junior high school students mathematics

achievement

\begin{tabular}{|c|c|c|c|c|c|}
\hline & $\begin{array}{l}\text { regression } \\
\text { coefficient }(b)\end{array}$ & standard error & $\begin{array}{l}\text { standardized regression } \\
\text { coefficient }(\beta)\end{array}$ & $T$ test & $\Delta R^{2}$ \\
\hline sex & -0.01 & 0.02 & -0.01 & -0.34 & \multirow{3}{*}{$\begin{array}{l}0.40^{*} \\
* *\end{array}$} \\
\hline grade & 0.01 & 0.01 & 0.01 & 0.52 & \\
\hline School position & -0.42 & 0.09 & -0.29 & $-4.73 * * *$ & \\
\hline
\end{tabular}


American Research Journal of Humanities and Social Sciences, Volume 1, Issue 5, 2015

ISSN 2378-7031

\begin{tabular}{|l|l|l|l|l|l|}
\hline School history & 0.02 & 0.00 & 0.27 & $9.17^{* * *}$ \\
\hline Per capita building area & 0.00 & 0.00 & 0.32 & $10.66^{* * *}$ \\
\hline Pupil ratio & -6.62 & 1.05 & -0.23 & $-6.29 * * *$ \\
\hline Senior professional & -24.24 & 1.26 & -0.68 & $-19.32^{* * *}$ \\
\hline Teaching expert ratio & 27.90 & 3.77 & 0.46 & $7.39^{* * *}$ \\
\hline Economic status & -0.03 & 0.02 & -0.04 & -1.68 \\
\hline Teacher age & 0.02 & 0.00 & 0.19 & $4.09^{* * *}$ & \\
\hline Teacher sex & -0.08 & 0.02 & -0.07 & $-3.62^{* * *}$ \\
\hline Teacher education & -0.02 & 0.04 & -0.01 & -0.44 & $0.03 *$ \\
\hline Teacher teaching time & -0.03 & 0.00 & -0.30 & $-6.27 * * *$ & $* *$ \\
\hline Average education years & -0.07 & 0.02 & -0.06 & $-2.84 * *$ \\
\hline Average length of service & -0.03 & 0.00 & -0.14 & $-7.22^{* * *}$ & \\
\hline
\end{tabular}

Table.3.5. Effect of class teacher's qualification on increment of junior high school student's English achievement

\begin{tabular}{|l|l|l|l|l|l|}
\hline & $\begin{array}{l}\text { regression } \\
\text { coefficient } \\
(b)\end{array}$ & $\begin{array}{l}\text { standard } \\
\text { error }\end{array}$ & $\begin{array}{l}\text { standardized regression } \\
\text { coefficient }(\beta)\end{array}$ & $T$ test & $\Delta R^{2}$ \\
\hline sex & 0.01 & 0.01 & 0.02 & 0.97 & 0.25 \\
\hline grade & 0.00 & 0.01 & 0.01 & $-8.46^{* * *}$ \\
\hline School position & -0.57 & 0.07 & -0.51 & $4.60^{* * *}$ \\
\hline School history & 0.01 & 0.00 & 0.13 & $15.81^{* * *}$ \\
\hline Per capita building area & 0.00 & 0.00 & 0.46 & -0.72 \\
\hline Pupil ratio & -0.59 & 0.82 & -0.03 & $-15.90^{* * * *}$ \\
\hline senior professional ratio & -15.52 & 0.97 & -0.55 & $11.51^{* * *}$ \\
\hline Teaching expert ratio & 33.64 & 2.92 & 0.70 & $-4.30^{* * *}$ \\
\hline Economic status & -0.07 & 0.02 & -0.09 & 0.26 \\
\hline Teacher age & 0.00 & 0.00 & 0.01 & -0.47 \\
\hline Teacher sex & -0.01 & 0.02 & -0.01 & $8.96^{* * *}$ \\
\hline Teacher education & 0.26 & 0.03 & 0.16 & $-3.29^{* * *}$ & \multirow{2}{*}{$0.05^{* *}$} \\
\hline Teacher teaching time & -0.01 & 0.00 & -0.15 & $8.19^{* * *}$ \\
\hline Average education years & 0.15 & 0.02 & 0.16 & $-2.96^{* *}$ & \\
\hline Average length of service & -0.01 & 0.00 & -0.06 & \\
\hline
\end{tabular}

In order to explore the influence of the teacher's qualification on the increment of students' learning achievement, we also carried out two-step hierarchical regression analysis. The first step is putting student's gender, grade, school location, founding history, per capita construction area, teacher-student ratio, senior titles ratio, teaching experts ratio, social economic status into regression equation; the second step is putting teacher tenure (teacher age, gender, education and age) qualification into the regression equation, the purpose is to investigate the pure effects of head teacher qualification on increment of students' Chinese learning achievement after controlled the first step of variables (the following analysis are also adopted in this approach.) 


\section{American Research Journal of Humanities and Social Sciences, Volume 1, Issue 5, 2015}

ISSN 2378-7031

Table 2-3 shows that student gender, grade, school location, founding history, per capita floor space (only the effect on Chinese language learning achievement incremental is not significant), teachers and students ratio (only the effect on English language learning achievement incremental is not significant), senior titles, teaching experts, social economic status (only the effect on English language learning achievement incremental is significant) such as can explain $26 \%$ of variation of students' Chinese language learning achievement and $40 \%$ variation of mathematics and English learning achievement; among them, gender, grade, school location, founding history, teacher-student ratio, middle and senior professional titles ratio and teaching experts ratio all have obvious and predicted effect on middle school students' English, Chinese and math learning performance significantly. Teacher education level and education length average years of have remarkable effect on incremental of students' English learning achievement. T-test reached 8.96. but negatively correlated with mathematics and Chinese language learning achievement incremental. This does not mean that the higher degree the Chinese and mathematics teachers have, the smaller the students' academic achievement, the only possible explanation is that Chinese and math class teacher's academic qualifications are more similar.

2.3.Influence of the teacher's qualification on the increment of students' academic achievement

Table.3.6. influence of class teacher's qualifications on increment of primary student's Chinese language achievement

\begin{tabular}{|l|l|l|l|l|l|}
\hline & $\begin{array}{l}\text { regression } \\
\text { coefficient }(b)\end{array}$ & $\begin{array}{l}\text { standard } \\
\text { error }\end{array}$ & $\begin{array}{l}\text { Standardizedregression } \\
\text { efficient }(\beta)\end{array}$ & $T$ test & $\Delta R^{2}$ \\
\hline sex & -0.12 & 0.06 & -0.05 & -1.89 & \\
\hline grade & 0.03 & 0.04 & 0.02 & 0.68 \\
\hline School position & 0.06 & 0.30 & 0.02 & 0.19 \\
\hline School history & 0.00 & 0.01 & 0.02 & 0.34 \\
\hline Per capita building area & -0.01 & 0.01 & -0.04 & -0.74 \\
\hline Pupil ratio & -2.63 & 2.27 & -0.07 & -1.16 \\
\hline senior professional ratio & 9.32 & 6.17 & 0.09 & 1.51 \\
\hline Teaching expert ratio & 13.36 & 14.06 & 0.15 & 0.95 \\
\hline Economic status & 0.02 & 0.04 & 0.01 & 0.35 \\
\hline Teacher age & 0.00 & 0.01 & -0.02 & -0.27 \\
\hline Teacher sex & -0.11 & 0.09 & -0.04 & -1.21 \\
\hline Teacher education & 0.08 & 0.10 & 0.02 & 0.80 \\
\hline Teacher teaching time & 0.01 & 0.01 & 0.04 & 0.67 \\
\hline Average education years & -0.08 & 0.03 & -0.07 & $-2.37 * *$ \\
\hline Average length of service & -0.02 & 0.01 & -0.14 & $-4.66^{* * *}$ \\
\hline
\end{tabular}

Table 2-6 and 2-7 shows, the nine variables, gender, grade, school location, founding history, per capita construction area, teachers and students ratio, senior titles ratio, teaching experts ratio and social economic status predict $1 \%$ variation of pupils math achievement; among them, founding history and senior titles ratio have significant effect and predictive on elementary students' mathematics learning achievement incremental. And all the above variables have no significant effect on the students' Chinese language learning achievement increment. In the control of the nine variables, gender, grade, school location, founding history, construction area per capita, teachers and students 
American Research Journal of Humanities and Social Sciences, Volume 1, Issue 5, 2015

ISSN 2378-7031

ratio, senior titles ratio, teaching experts ratio and social economic status, teacher age, teacher gender, teacher education, teacher title, education average age and average length of service can significantly predict $2 \%$ increment of students' Chinese and mathematics achievement. The average length of service of head teacher and the Chinese teachers' average age of education were significantly negatively correlated with the grade of the primary school students' Chinese language learning. The teachers' age and educational background were significantly positively correlated with the increment of students' mathematics learning achievement. T tests were 2.96 and 2.79, respectively.

Table.3.7. influence of class teacher's qualifications on increment of primary student's Chinese language achievement

\begin{tabular}{|l|l|l|l|l|l|}
\hline & $\begin{array}{l}\text { regression } \\
\text { coefficient }(b)\end{array}$ & standard error & $\begin{array}{l}\text { standardized regression } \\
\text { coefficient }(\beta)\end{array}$ & $T$ test & $\Delta R^{2}$ \\
\hline sex & -0.03 & 0.06 & -0.01 & -0.43 & \\
\hline grade & 0.01 & 0.04 & 0.01 & 0.35 \\
\hline School position & -0.33 & 0.27 & -0.14 & -1.22 \\
\hline School history & 0.02 & 0.01 & 0.17 & $3.39 * * *$ \\
\hline Per capita building area & 0.02 & 0.01 & 0.10 & 1.88 \\
\hline Pupil ratio & 0.46 & 2.05 & 0.01 & 0.01 \\
\hline senior professional ratio & -12.98 & 5.58 & -0.14 & $-2.33^{*}$ \\
\hline Teaching expert ratio & 0.82 & 12.72 & 0.01 & 0.07 \\
\hline Economic status & 0.01 & 0.04 & 0.01 & 0.24 \\
\hline Teacher age & 0.03 & 0.01 & 0.18 & $2.96^{* *}$ \\
\hline Teacher sex & 0.10 & 0.09 & 0.04 & 1.12 \\
\hline Teacher education & 0.26 & 0.09 & 0.08 & $2.79 * *$ \\
\hline Teacher teaching time & -0.02 & 0.01 & -0.17 & $-2.88^{* *}$ \\
\hline Average education years & -0.01 & 0.03 & -0.01 & -0.46 \\
\hline Average length of service & -0.01 & 0.00 & -0.05 & -1.51 & \\
\hline
\end{tabular}

III. DiscuSSION AND ANALYSIS

Through the analysis of the above results, we get the following conclusions:

3.1. In increases of student achievement, in general, the higher head teachers and subject teachers education is, the bigger and more student achievement increase, That means teacher education is conducive to enhancing the students' grades and achievement increase. This is consistent with the results of interviews with some students, the higher the degree of teacher education, that can give students a better impact.

3.2 In increase of students' learning achievement, that not mean the older teacher's age is, the longer of teacher's service is, the quicker students' learning achievement develop. Only the teacher's length of teaching service close to the average length of all teachers. Then the teacher can have remarkable and positive effect on the increment of the students learning achievement. That means the teacher who is in middle age has richer experience and energy in improving students' academic performance than the new teacher or the elder teacher.

3.3. The effect of socioeconomic status on the changes of students' academic performance is not significant, which 
American Research Journal of Humanities and Social Sciences, Volume 1, Issue 5, 2015

ISSN 2378-7031

shows that the effect of family socioeconomic status on increase of students' academic performance is not obvious.

3.4. Except inconspicuously effect to the primary Chinese language learning achievement increment, middle and primary school founding history has significant effect not only on primary student academic performance, but also has significant effect on middle school student academic performance, That means the longer the school founding history is , the higher the teaching quality of the school is . the quicker student's academic performance raising.

3.5.Except for the junior middle school Chinese language learning achievement, whether in primary school or in the middle school, the student subjects learning incremental results no significant gender differences.

3.6. Except conspicuously effect to the junior middle Chinese language learning achievement increment, both in the middle school or in the primary school. That means students' academic achievement does not increase with the increase of the proportion of senior professional titles, which indicates that the teacher's senior professional title does not necessarily lead to the improvement of students' academic performance.

The above is the interpretation of the results of this paper, for a more objective facts, this paper also carried out the family, school, level two and three multiple analysis.

\section{REFERENCES}

[1] Lei shan Shi. The relationship between family economic status and learning involvement: the mediating effect of academic self efficacy [J] psychological development and education, 2013, (1).72.

[2] Angrist, J. and Lavy, V.(1999), 'Using Maimondies' Rule to Estimate the Effect of Class Size on Scholastic Achievement', Quarterly Journal of Economics, 114(2), pp.533-575.

[3] Angrist and Lang.(2004), 'Does school integration generate peer effects? Evidence from Boston's Metco program', American Economic Review, 94, 1613-1634.

[4] Anna Vignoles; Rosalind Levacic; James Walker; Stephen Machin ;David Reynolds.(2000), 'The Relationship Between Resource Allocation and Pupil Attainment: A Review', The Department of Education and Employment Research Report, 228.

\section{AUTHOR'S BIOGRAPHY}

Zhiquan zhang, (1972-), male, born in Yanzhou county Shandong province, vice professor of Nantong university, doctor, research on educational principle theory.TL:13814717635 